\title{
EKSPRESI BCL-2 PADA NEOPLASMA EPITELIAL OVARIUM JINAK, BORDERLINE, DAN GANAS SERTA KORELASINYA DENGAN DERAJAT HISTOPATOLOGIK
}

\author{
Rose Khasana Dewi ${ }^{\star 凶}$, Arif Satria Hardika*, Diah Prabawati Retnani*, Harun Al Rasyid ${ }^{\star *}$
}

\begin{abstract}
Abstrak
Neoplasma epitelial ovarium diklasifikasikan menjadi 3 kategori yaitu jinak, borderline, dan ganas. Neoplasma ganas ovarium termasuk dalam sepuluh besar penyebab kematian tersering akibat kanker pada perempuan di dunia. Penentuan kategori neoplasma ovarium kadang masih menjadi masalah karena dipengaruhi oleh beberapa faktor, termasuk proliferasi dan apoptosis sel serta invasi stroma. Bcl-2 (B-cell lymphoma 2) merupakan salah satu protein prosurvival yang berfungsi sebagai antiapoptosis dan cukup berperan dalam perkembangan neoplasma. Tujuan penelitian ini adalah untuk mengetahui perbedaan ekspresi Bcl-2 pada neoplasma epitelial ovarium jinak, borderline, ganas serta untuk mengungkap hubungan ekspresi Bcl-2 dengan derajat histopatologik pada neoplasma ganas. Penelitian ini merupakan penelitian analitik cross-sectional. Sampel penelitian berupa 35 blok parafin kasus neoplasma ovarium serosum dan musinosum (13 jinak, 8 borderline, 14 ganas) di RSUD Dr. Saiful Anwar Malang periode 2016-2017. Kelompok neoplasma ganas terdiri dari masing-masing 5 kasus derajat 1 dan $3(35,7 \%)$ serta 4 kasus derajat 2 $(28,6 \%)$. Perbedaan ekspresi pulasan imunohistokimia Bcl-2 antara neoplasma jinak, borderline, dan ganas dianalisis menggunakan uji Kruskal-Wallis, sedangkan korelasinya dengan derajat histopatologik dianalisis menggunakan uji korelasi Spearman. Hasil penelitian menunjukkan ekspresi Bcl-2 tidak berbeda signifikan antara neoplasma jinak, borderline, dan ganas $(p=0,159)$. Bcl-2 pada neoplasma ganas menunjukkan ekspresi yang semakin rendah dengan meningkatnya derajat histopatologik $(p=0,021$ dan $r=-0,608)$. Kesimpulannya, tidak terdapat perbedaan ekspresi Bcl-2 yang signifikan antara neoplasma epitelial ovarium jinak, borderline, dan ganas. Ekspresi Bcl-2 berkorelasi negatif yang kuat dengan derajat histopatologik pada neoplasma ganas.
\end{abstract}

Kata kunci: Bcl-2, derajat histopatologik, neoplasma ovarium.

\section{BCL-2 EXPRESSION IN BENIGN, BORDERLINE, MALIGNANT OVARIAN EPITHELIAL NEOPLASMS, AND ITS CORRELATION WITH HISTOPATHOLOGICAL GRADE}

\begin{abstract}
Epithelial ovarian neoplasms are classified into three categories: benign, borderline and malignant. Malignant ovarian neoplasm turns out to be in the top ten most leading cause of cancer death in women worldwide. Cellular proliferation and apoptosis also stromal invasion take parts in determining the category of ovarian neoplasms, which sometimes still becomes a problem. Bcl-2 (B-cell lymphoma 2 ) is a prosurvival protein that causes it acts as an anti-apoptotic protein and plays a role in tumor development. This study aims to investigate $\mathrm{Bcl}-2$ expression in benign, borderline, malignant ovarian epithelial neoplasms as well as to reveal its correlation with histopathological grade in malignant neoplasms. An analytical cross-sectional study was conducted on a total of 35 paraffin blocks of ovarian serous and mucinous neoplasms which consisted of 13 benign, 8 borderline, and 14 malignant cases in Dr. Saiful Anwar General Hospital Malang within 2016-2017. Malignant category consisted of 5 each grade 1 and grade 3 cases (35.7\%), also 4 grade 2 cases (28.6\%). Bcl-2 immunoexpression comparison between benign, borderline and malignant category was analyzed with the Kruskal-Wallis test; whereas its correlation with histopathological grade was analyzed with Spearman's rho test. Results showed no significant differences in Bcl-2 expression in benign, borderline, and malignant neoplasms. Bcl-2 in malignant neoplasms shows lower expression in higher histopathological grades $(p=0.021$ and $r=-0.608)$. This study concludes that $B c l-2$ expression is not significantly different between benign, borderline, and malignant epithelial ovarian neoplasms. Bcl-2 expression is found to be negatively correlated with histopathological grade in malignant neoplasms.
\end{abstract}

Keywords: Bcl-2, histopathological grade, ovarian neoplasms.

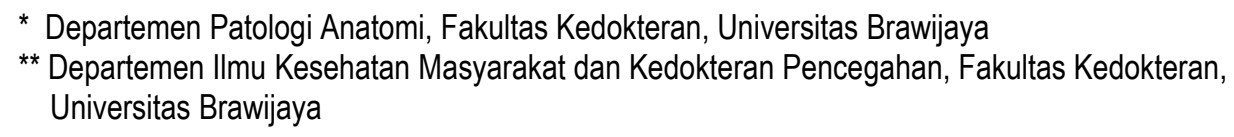

E-mail: rosenade.dr@gmail.com 


\section{Pendahuluan}

Neoplasma epitelial ovarium terbagi menjadi jinak, borderline, dan ganas menurut World Health Organization (WHO) 2014. ${ }^{1}$ Data GLOBOCAN tahun 2012 menunjukkan bahwa neoplasma ganas epitelial (karsinoma) ovarium merupakan keganasan tersering urutan ketujuh di dunia yang mengenai perempuan. Kurang lebih 152.000 kasus kematian yang ditemukan menjadikan karsinoma ovarium sebagai penyebab kematian tersering urutan kedelapan akibat kanker pada perempuan di dunia. ${ }^{2}$ Data Badan Registrasi Kanker (BRK) tahun 2014 menunjukkan neoplasma ovarium sebagai neoplasma terbanyak ketiga pada perempuan di Indonesia setelah neoplasma payudara dan neoplasma leher rahim. ${ }^{3}$

Pasien dengan neoplasma ganas ovarium sering tidak menimbulkan gejala. Hal ini menyebabkan pasien baru terdiagnosis setelah tumor memasuki stadium lanjut dan mengalami penyebaran ke tempat lain. $4,5 \mathrm{NeO}-$ plasma tipe epitelial menempati sekitar $90 \%$ dari seluruh keganasan pada ovarium. 6,7 Subtipe serosum adalah subtipe histopatologi yang paling banyak ditemukan. ${ }^{7}$

Neoplasma yang dikategorikan sebagai borderline memiliki karakteristik berupa proliferasi seluler dengan sel yang menunjukkan atipia inti, namun tidak ditemukan adanya invasi destruktif pada stroma. ${ }^{8}$ Meskipun kriteria penentuan neoplasma borderline telah diketahui, namun dalam penerapannya masih merupakan suatu masalah. ${ }^{9}$

Diagnosis neoplasma ovarium borderline saat preoperatif sangat sulit, karena karakteristik makroskopiknya secara radiologi dapat menyerupai tumor jinak maupun tumor ganas. ${ }^{10}$ Neoplasma borderline dapat dibedakan dari neoplasma jinak dan neoplasma ganas, karena memiliki karakteristik dan perilaku klinis yang berbeda. ${ }^{9}$ Sebagian besar neoplasma borderline terbatas pada ovarium dan memiliki prognosis yang baik setelah tindakan operasi, namun dapat pula rekuren atau mengalami progresi menjadi neoplasma ganas pada sekitar 15\% kasus. ${ }^{11}$ Neoplasma borderline juga dapat meluas ke ekstra ovarium (peritoneum) meskipun bersifat indolen. ${ }^{12}$

$\mathrm{Bcl}-2$ termasuk dalam $\mathrm{Bcl}-2$ family proteins yang berfungsi meregulasi apoptosis melalui jalur intrinsik (mitokondrial-dependen). Apoptosis berpengaruh tehadap pertumbuhan neoplasma, karena homeostasis sel dipengaruhi oleh keseimbangan antara kecepatan proliferasi dan apoptosis sel. ${ }^{13}$ Keseimbangan antara protein proapoptotik dan protein prosurvival sangat penting. Ketidakseimbangan kedua kelompok protein tersebut dapat mengakibatkan hambatan apoptosis sehingga memfasilitasi tranformasi onkogenik, pertumbuhan tumor, juga resistensi terhadap kemoterapi. ${ }^{14,15}$

Terdapat perbedaan yang signifikan ekspresi Bcl-2 yang lebih tinggi pada adenokarsinoma ovarium dibandingkan dengan tumor borderline. ${ }^{16}$ Namun, bukti lain menyebutkan bahwa ekspresi $\mathrm{Bcl}-2$ lebih rendah pada tumor ganas dibandingkan pada tumor jinak ovarium. ${ }^{13}$

Penelitian ini bertujuan untuk mengetahui perbedaan imunoekspresi $\mathrm{Bcl}-2$ pada neoplasma epitelial ovarium jinak, borderline, dan ganas. Selain itu, juga untuk mengetahui ada tidaknya hubungan antara ekspresi Bcl-2 dengan derajat histopatologik neoplasma ganas. Adanya pengetahuan tentang perbedaan ekspresi Bcl-2 antara neoplasma jinak, borderline, dan neoplasma ganas dengan berbagai derajat histopatologik, diharapkan dapat menjadi dasar penggunaan imunoekspresi protein $\mathrm{Bcl}-2$ sebagai modalitas pendukung diagnostik dan prognostik pada neoplasma epitelial ovarium.

\section{Bahan dan Metode}

\section{Desain Penelitian}

Penelitian ini dirancang menggunakan desain penelitian analitik cross-sectional. 
Sampel yang digunakan adalah blok parafin dari kasus neoplasma epitelial ovarium jinak, borderline, dan ganas tipe serosum dan musinosum yang didiagnosis secara histopatologik di Instalasi Patologi Anatomi RSUD Dr. Saiful Anwar Malang periode tahun 2016-2017. Kriteria eksklusi sampel adalah blok parafin rusak atau tidak dapat ditemukan; sediaan mengandung area nekrotik luas; dan sediaan berasal dari kasus yang telah mendapat kemoterapi sebelumnya.

Sampel yang representatif dan memenuhi kriteria inklusi didapatkan sebanyak 35 kasus. Seluruh kasus dilakukan pembacaan ulang secara mikroskopik dan dikategorikan sebagai neoplasma jinak, borderline, atau ganas berdasarkan kriteria WHO tahun 2014. Sediaan neoplasma ganas juga diklasifikasikan berdasarkan derajat histopatologiknya menurut kriteria Silverberg grading system. Komponen yang dievaluasi untuk menentukan derajat histopatologik adalah arsitektur (skor 1 = glandular; 2 = papiler; 3 = solid), atipia inti (skor 1 = ringan; 2 = sedang, $3=$ berat), dan jumlah mitosis/10 LPB (skor $1=0-9 / 10 \mathrm{LPB}$; skor $2=10-24 / 10 \mathrm{LPB}$; skor $3=\geq 25 / 10 \mathrm{LPB}$ ). Seluruh skor dijumlahkan dan menghasilkan total skor yang dikategorikan sebagai derajat 1 (skor 3-5); derajat 2 (skor 6-7); derajat 3 (skor $8-9) .{ }^{17}$

\section{Pulasan Imunohistokimia (IHK)}

Blok parafin dari kasus yang telah dibaca ulang, dilakukan pemotongan menggunakan mikrotom dengan ketebalan $4 \mu \mathrm{m}$ dan ditempelkan pada poly--lysine coated slide. Deparafinisasi menggunakan xylol dan rehidrasi menggunakan alkohol konsentrasi menurun. Larutan hydrogen peroxide digunakan untuk proses blocking aktivitas endogen peroksidase. Tahapan antigen retrieval menggunakan prinsip heat-induced dengan direndam dalam antigen retrieval buffer solution dan dimasukkan ke dalam decloacking chamber, $90{ }^{\circ} \mathrm{C} ; \pm 45$ menit. Inkubasi antibodi primer menggunakan mouse monoclonal BCl-2 antibody (Biocare Medical, CM $003 \mathrm{~A}, \mathrm{C})$, dilusi 1:200, \pm 60 menit. Inkubasi polymer-based secondary antibody, \pm 30 menit, dilanjutkan inkubasi 3,3'Diaminobenzidine $(D A B)$ chromogen, \pm 10 menit. Pulasan counterstaining menggunakan Hematoxyllin, dilanjutkan proses dehidrasi menggunakan alkohol bertingkat, clearing dengan larutan xylol, dan proses mounting. Pulasan kontrol positif menggunakan sediaan tonsil.

\section{Evaluasi Ekspresi Bcl-2}

Hasil pulasan imunohistokimia diamati menggunakan mikroskop cahaya binokuler, merk Olympus CX23 dengan pembesaran 400x. Ekspresi Bcl-2 akan tampak sebagai warna coklat pada sitoplasma atau membran inti sel epitelial tumor. Persentase dihitung dari banyaknya jumlah sel yang positif mengekspresikan Bcl-2 dari 200 sel epitel tumor per lapang pandang dikalikan $100 \%$. Persentase ekspresi Bcl-2 dihitung pada 5 lapang pandang di area yang paling representatif. Seluruh preparat dibaca secara acak tanpa mengetahui data klinis maupun histopatologisnya (blind).

\section{Analisis Statistik}

Hasil perhitungan ekspresi Bcl-2 akan dibandingkan antara kelompok neoplasma jinak, borderline, dan ganas. Sebelumnya, dilakukan uji normalitas data terlebih dahulu menggunakan uji Shapiro-Wilk. Bila distribusi data normal, akan dilanjutkan dengan analisis komparatif menggunakan uji one way ANOVA. Namun bila distribusi data tidak normal, analisis komparatif menggunakan uji KruskalWallis. Bila analisis komparatif menunjukkan nilai yang signifikan $(p<0,05)$, akan dilanjutkan dengan uji post hoc untuk mengetahui perbedaan antar masing-masing kelompok. Ekspresi Bcl-2 juga akan dianalisis korelasinya dengan derajat histopatologik hanya pada kasus neoplasma ganas dengan menggunakan uji korelasi Spearman. 


\section{Hasil}

\section{Karakteristik Sampel}

Penelitian ini dilakukan terhadap 35 sampel yang memenuhi kriteria inklusi. Karakteristik klinikopatologi dari seluruh sampel dapat dilihat pada Tabel 1. Sampel penelitian memiliki rentang usia antara 30 hingga 72 tahun dengan lebih dari separuh sampel $(62,9 \%)$ berusia 50 tahun ke atas. Rata-rata usia pasien adalah 51,49 tahun. Sebagian besar sampel berukuran lebih dari sama dengan $20 \mathrm{~cm}(54,3 \%)$ dengan rata-rata ukuran tumor $19,21 \mathrm{~cm}$. Sampel terdiri dari 13 kasus neoplasma jinak $(37,1 \%), 8$ kasus neoplasma borderline $(22,9 \%)$, serta 14 kasus neoplasma ganas (40\%). Dari seluruh kasus neoplasma ganas, didapatkan 5 kasus derajat 1 (35,7\%); 4 kasus derajat 2 (28,6\%); dan 5 kasus derajat $3(35,7 \%)$. Subtipe histopatologi dari sampel terbagi menjadi subtipe serosum sebanyak 15 kasus $(42,9 \%)$ dan musinosum sebanyak 20 kasus $(57,1 \%)$.
Perbandingan Ekspresi Bcl-2 antara Neoplasma Jinak, Borderline, Ganas

Ekspresi Bcl-2 dengan pulasan imunohistokimia pada neoplasma jinak memiliki rentang antara 4,6\%-93,3\% dengan median $39,2 \%$ dan rata-rata $45,0 \%$. Rentang ekspresi $\mathrm{Bcl}-2$ pada neoplasma borderline antara $3,4 \%$ $-45 \%$ dengan median $18,6 \%$ dan rata-rata $20,0 \%$. Neoplasma ganas memiliki rentang ekspresi $\mathrm{Bcl}-2$ antara $3,2 \%-87,5 \%$ dengan median $18,6 \%$ dan rata-rata $25,7 \%$. Hasil pulasan IHK ditunjukkan pada Gambar 1. Uji Shapiro-Wilk menunjukkan neoplasma ganas memiliki distribusi tidak normal $(p=0,02)$, sehingga tidak memenuhi syarat untuk dianalisis menggunakan uji komparatif one way ANOVA. Analisis komparatif dapat dilakukan menggunakan uji non parametrik Kruskal-Wallis. Hasil analisis menunjukkan tidak terdapat perbedaan ekspresi Bcl-2 yang signifikan antara kelompok neoplasma jinak, borderline, dan ganas $(p=0,159)$ seperti yang tertera pada Tabel 2 .

Tabel 1. Karakteristik klinikopatologi neoplasma epitelial ovarium $(n=35)$.

\begin{tabular}{|c|c|c|c|}
\hline Karakter & Frekuensi (f) & Persentase (\%) & Keterangan \\
\hline \multicolumn{4}{|c|}{ Kelompok usia (tahun) } \\
\hline$<50$ & 13 & 37,1 & min-maks: $30-72$ \\
\hline$\geq 50$ & 22 & 62,9 & rerata $\pm S D: 51,49 \pm 10,34$ \\
\hline \multicolumn{4}{|l|}{ Ukuran tumor $(\mathrm{cm})$} \\
\hline$<20$ & 16 & 45,7 & min-maks: $2,5-48$ \\
\hline$\geq 20$ & 19 & 54,3 & rerata $\pm S D: 19,21 \pm 9,81$ \\
\hline \multicolumn{4}{|l|}{ Perilaku biologi } \\
\hline Jinak & 13 & 37,1 & \\
\hline Borderline & 8 & 22,9 & \\
\hline Ganas & 14 & 40,0 & \\
\hline Derajat 1 & 5 & 35,7 & \\
\hline Derajat 2 & 4 & 28,6 & \\
\hline Derajat 3 & 5 & 35,7 & \\
\hline \multicolumn{4}{|l|}{ Subtipe histopatologi } \\
\hline Serosum & 15 & 42,9 & \\
\hline Musinosum & 20 & 57,1 & \\
\hline
\end{tabular}


Tabel 2. Hasil analisis statistik perbedaan ekspresi Bcl-2 pada neoplasma jinak, borderline, dan ganas $(n=35)$.

\begin{tabular}{lccccc}
\hline Kategori & $\mathrm{n}$ & \multicolumn{2}{c}{ Ekspresi Bcl-2 $(\%)$} & Distribusi Data & Nilai $\mathrm{p}$ \\
\cline { 3 - 4 } Neoplasma & & median (min-maks) & mean \pm SD & (Uji Shapiro-Wilk) & (Uji Kruskal-Wallis) \\
\hline Jinak & 13 & $39,20(4,60-93,30)$ & $45,0 \pm 34,5$ & $p=0,063$ & $p=0,159$ \\
Borderline & 8 & $18,60(3,40-45,00)$ & $20,0 \pm 15,8$ & $p=0,281$ & \\
Ganas & 14 & $18,50(3,20-87,50)$ & $25,7 \pm 27,0$ & $p=0,02$ & \\
\multicolumn{7}{l}{ Keterangan: Uji Kruskal-Wallis. Tidak dilakukan analisis post hoc $(p>0,05)}$. & \\
\hline
\end{tabular}
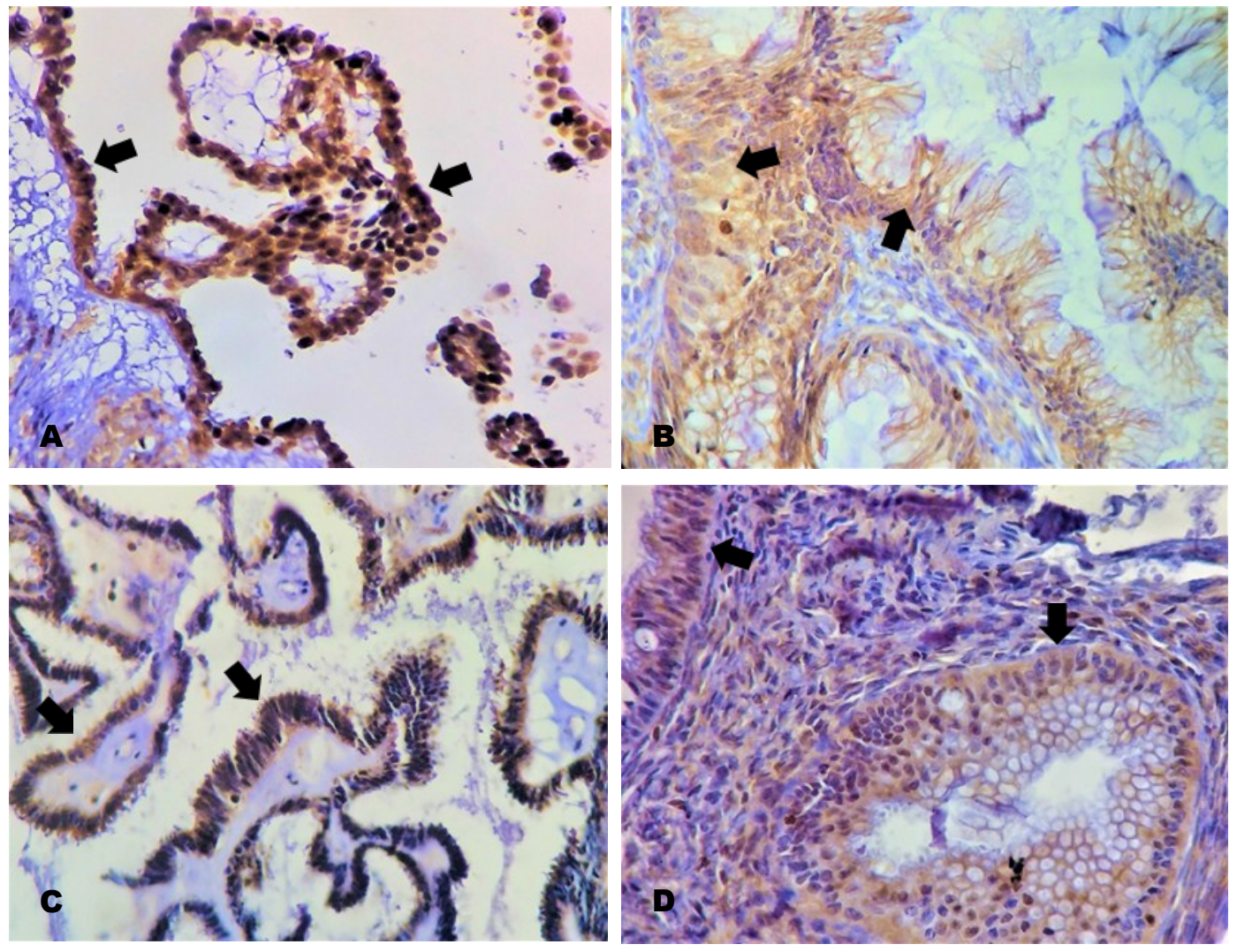

Gambar 1. Ekspresi Bcl-2 pada neoplasma jinak \& borderline pada tipe serosum dan musinosum (tanda panah hitam).

Keterangan: A. Ekspresi Bcl-2 pada neoplasma jinak serosum (pembesaran 400x) B. Ekspresi Bcl-2 pada neoplasma jinak musinosum (pembesaran 400x) C. Ekspresi Bcl-2 pada neoplasma borderline serosum (pembesaran 400x) D. Ekspresi Bcl-2 pada neoplasma borderline musinosum

Hubungan Ekspresi Bcl-2 dengan Derajat Histopatologik pada Neoplasma Ganas

Neoplasma ganas derajat 1 menunjukkan nilai rata-rata ekspresi Bcl-2 50,7\%, $10,7 \%$ pada neoplasma ganas derajat 2 dan $12,7 \%$ pada neoplasma ganas derajat 3 . Hasil pulasan IHK dapat dilihat pada Gambar 2. Hasil perhitungan ekspresi Bcl-2 dilakukan uji statistik menggunakan uji korelasi Spearman untuk mencari ada tidaknya hubungan dengan derajat histopatologik. Hasil uji statistik menunjukkan adanya korelasi yang signifikan ( $p=0,021)$ antara ekspresi Bcl-2 dengan derajat histopatologik berupa korelasi negatif yang kuat $(r=-0,608)$ seperti tertera pada Tabel 3. 
Tabel 3. Hasil analisis korelasi ekspresi Bcl-2 dengan derajat histopatologik neoplasma ganas $(n=14)$.

\begin{tabular}{lccc}
\hline $\begin{array}{c}\text { Derajat } \\
\text { Histopatologik }\end{array}$ & $f(\%)$ & $\begin{array}{c}\text { Ekspresi Bcl-2 }(\%) \\
\text { rerata } \pm \text { SD }\end{array}$ & $\begin{array}{c}\text { Nilai p } \\
\text { (Uji korelasi Spearman) }\end{array}$ \\
\hline Derajat 1 & $5(35,7)$ & $50,7 \pm 31,7$ & $p=0,021$ \\
Derajat 2 & $4(28,6)$ & $10,7 \pm 8,3$ & \\
Derajat 3 & $5(35,7)$ & $12,7 \pm 10,3$ & \\
Keterangan: Uji korelasi Spearman's rho. Nilai koefisien korelasi $r=-0.608$ & \\
\hline
\end{tabular}
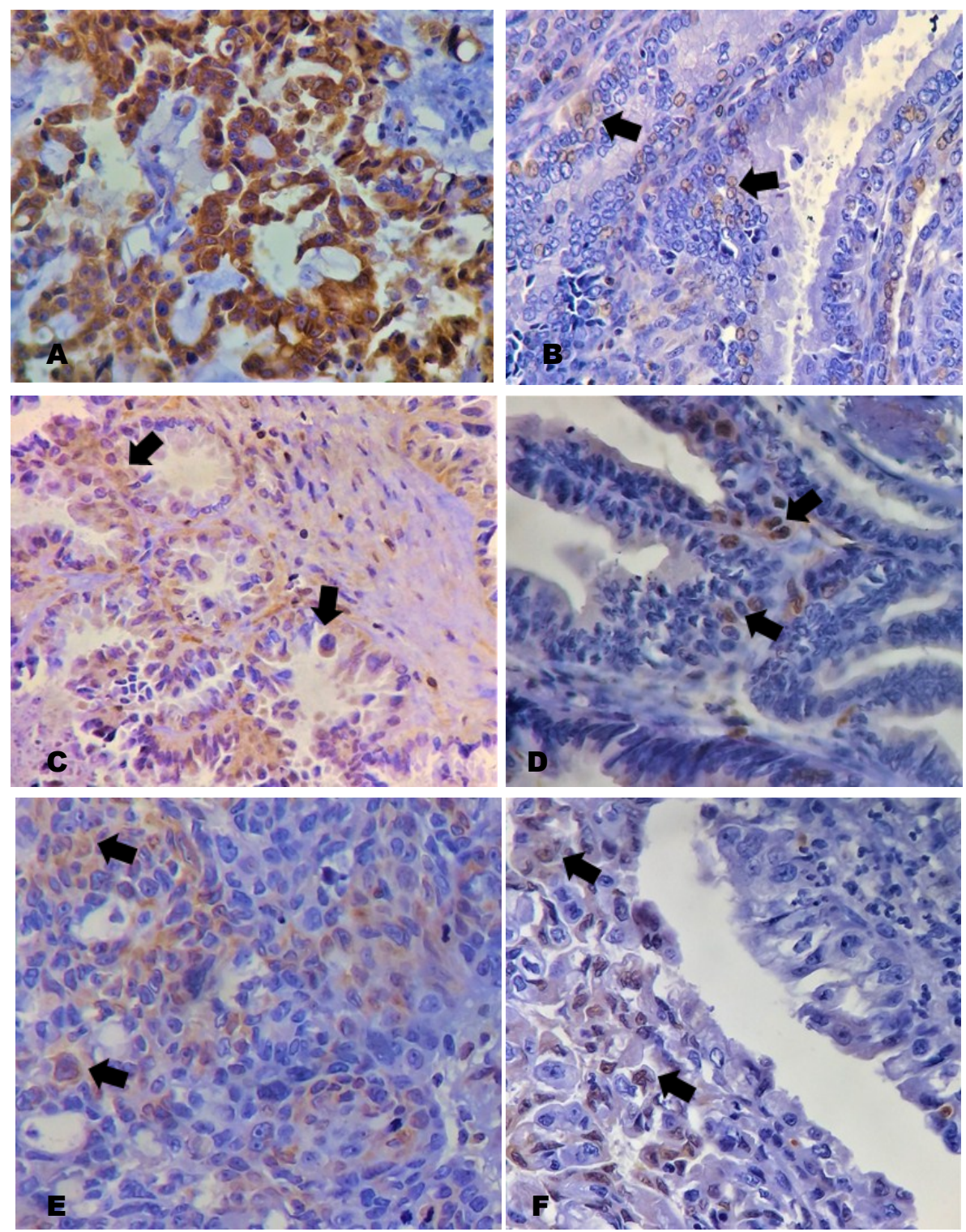

Gambar 2. Ekspresi Bcl-2 pada neoplasma ganas serosum dan musinosum.

Keterangan: A. Ekspresi Bcl-2 pada neoplasma ganas serosum derajat 1 (pembesaran 400x), B. Ekspresi Bcl-2 pada neoplasma ganas musinosum derajat 1 (pembesaran 400x). C. Ekspresi Bcl-2 pada neoplasma ganas serosum derajat 2 (pembesaran 400x) D. Ekspresi Bcl-2 pada neoplasma ganas musinosum derajat 2 (pembesaran 400x), E. Ekspresi Bcl-2 pada neoplasma ganas serosum derajat 3 (pembesaran 400x), F. Ekspresi Bcl-2 pada neoplasma ganas 


\section{Pembahasan}

Menurut Klasifikasi WHO, neoplasma epitelial pada ovarium dapat dikategorikan menjadi neoplasma jinak, neoplasma borderline, dan neoplasma ganas. ${ }^{1}$ Pada penelitian ini didapatkan distribusi neoplasma jinak sebesar $37,1 \%$, neoplasma borderline sebesar $22.9 \%$, dan neoplasma ganas sebesar $40 \%$. Literatur menyebutkan neoplasma jinak, borderline, dan ganas bertanggung jawab terhadap $60 \%, 5 \%$, dan $35 \%$ dari seluruh kasus neoplasma epitelial. ${ }^{17}$

Hasil penelitian ini menunjukkan neoplasma ganas dengan derajat rendah hanya didapatkan pada sekitar $35,7 \%$ kasus. Hal ini sesuai dengan literatur yang menyebutkan bahwa karsinoma serosum derajat rendah lebih jarang ditemukan ( $<10 \%)$ dibandingkan dengan derajat tinggi. ${ }^{17}$

$\mathrm{Bcl}-2$ merupakan protein yang meregulasi apoptosis dan ditemukan overekspresi pada berbagai neoplasma ganas termasuk pada karsinoma ovarium. ${ }^{15,16} \mathrm{Bcl}-2$ menghambat apoptosis melalui jalur mitokondria intrinsik sebagai respons terhadap adanya kerusakan DNA.14,15,18 Pertumbuhan neoplastik tidak hanya disebabkan oleh adanya proliferasi sel tetapi juga akibat penurunan kematian sel. Oleh karena itu keseimbangan antara protein pro dan antiapoptotik sangat penting. 13,14

Ekspresi Bcl-2 pada penelitian ini menunjukkan nilai rerata yang lebih tinggi pada neoplasma jinak (45\%) dibandingkan pada neoplasma borderline (20\%) dan neoplasma ganas $(25,7 \%)$. Hal ini tidak sesuai dengan teori di atas dan dengan penelitian yang dilakukan oleh Zeren et al. yang menyebutkan terdapat keseimbangan imunoreaktifitas $\mathrm{Bcl}-2$ dan Bax pada tumor borderline. Namun, keseimbangan tersebut menjadi berubah pada adenokarsinoma ovarium yang mengekspresikan $\mathrm{Bcl}-2$ secara kuat namun lemah terhadap Bax dan p53.16
Hal ini dapat dijelaskan berdasar pada literatur yang menyebutkan bahwa terdapat domain yang meregulasi p53 pada gen $\mathrm{Bcl}-2$ yang tidak ditranslasikan, yang dapat menghambat ekspresi Bcl-2. Hal ini menunjukkan bahwa downregulation ekspresi $\mathrm{Bcl}-2$ dapat merupakan akibat dari efek inhibisi ekspresi p53 pada Bcl-2 selama proses karsinogenesis neoplasma ovarium. ${ }^{19}$ Oleh karena itu, sebagian besar penelitian yang mengevaluasi ekspresi Bcl-2, juga melakukan evaluasi p53, Bax, atau protein proapoptotik lainnya untuk mengetahui hubungannya.

Penelitian yang dilakukan oleh Chaudhry et al. juga menunjukkan ekspresi protein antiapoptotik $\mathrm{Bcl}-2$ yang lebih tinggi pada tumor jinak, sedangkan tumor ganas mengekspresikan protein proapoptotik Bax yang lebih tinggi. ${ }^{13} \mathrm{Hal}$ ini sesuai dengan hasil yang didapatkan pada penelitian ini. Demikian pula dengan penelitian yang dilakukan oleh Gursan et al. yang menunjukkan overekspresi $\mathrm{Bcl}-2$ hanya didapatkan pada neoplasma jinak dan borderline, sedangkan neoplasma ganas hanya menunjukkan imunoreaktifitas sedang. Pada penelitian tersebut juga didapatkan korelasi yang negatif antara ekspresi $\mathrm{Bcl}-2$ dengan ekspresi p53.20

Perbandingan ekspresi $\mathrm{Bcl}-2$ pada penelitian ini tidak menunjukkan adanya perbedaan yang signifikan antara neoplasma jinak, borderline, maupun ganas dengan nilai $p=0,159(p>0.05)$. Hal ini sejalan dengan penelitian yang dilaporkan oleh Ozer et al. yang menyebutkan bahwa pulasan $\mathrm{Bcl}-2$ pada tumor serosum jinak, borderline, dan ganas sama-sama menunjukkan hasil yang positif, namun tidak menunjukkan perbedaan yang signifikan secara statistik. ${ }^{21}$ Penelitian oleh Arik et al. juga menyimpulkan bahwa tidak terdapat perbedaan ekspresi Bcl-2 antara kategori jinak, borderline, dan ganas pada tumor serosum. ${ }^{22}$

Pada penelitian ini, ekspresi Bcl-2 juga dihubungkan dengan derajat histopatologik neoplasma ganas. 
Hasil penelitian menunjukkan korelasi negatif yang kuat ( $p=0,021 ; r=-0,608)$ antara ekspresi Bcl-2 dengan derajat histopatologik. Artinya semakin tinggi derajat histopatologiknya, ekspresi protein Bcl-2 akan semakin rendah dan sebaliknya. Hal ini sesuai dengan penelitian yang dilakukan oleh Anderson et al. yang menyebutkan penurunan intensitas ekspresi Bcl-2 berkaitan dengan derajat tumor yang lebih tinggi, namun perbedaannya tidak signifikan secara statistik. ${ }^{15}$

Penelitian lain juga menyebutkan bahwa ekspresi protein Bcl-2 pada karsinoma ovarium serosum derajat 1 dan 2 menunjukkan hasil yang sebanding, namun menunjukkan hasil yang negatif pada derajat 3.22 Pada literatur disebutkan bahwa penurunan ekspresi Bcl-2 sejalan dengan progres tumor. Hal ini merupakan konsekuensi dari adanya disregulasi protein $\mathrm{Bcl}-2$ yang secara normal diperlukan untuk dapat mempertahankan fungsi fisiologis dan integritas dari epitel permukaan ovarium. ${ }^{19}$

Penelitian oleh Anderson et al. juga menyebutkan kadar $\mathrm{Bcl}-2$ urin meningkat pada karsinoma ovarium dibanding normal atau neoplasma jinak. Hal ini menunjukkan penurunan ekspresi $\mathrm{Bcl}-2$ pada sel epitel dengan meningkatnya progres tumor dapat dipahami sebagai suatu transisi dari ekspresi seluler menjadi Bcl-2 yang disekresikan sejalan dengan progres tumor. ${ }^{15,23}$

\section{Kesimpulan}

Penelitian ini menunjukkan tidak terdapat perbedaan ekspresi Bcl-2 yang signifikan antara kelompok neoplasma epitelial ovarium jinak, borderline, maupun ganas. Penelitian ini juga menunjukkan bahwa imunoekspresi Bcl-2 memiliki korelasi negatif dengan derajat histopatologik neoplasma ganas epitelial yang artinya semakin tinggi derajat neoplasma ganas, maka semakin rendah ekspresi Bcl-2, atau sebaliknya.

\section{Saran}

Penelitian mengenai ekspresi Bcl-2 pada neoplasma ovarium perlu dilakukan lebih lanjut terutama dengan jumlah sampel yang lebih banyak dan dapat dilakukan bersama dengan evaluasi mutasi p53, rasio dengan protein Bax atau protein proapoptotik lainnya. Penelitian yang mengevaluasi faktor penentu keganasan lainnya seperti adanya invasi stroma, angioinvasi, atau metastasis pada neoplasma ovarium juga masih perlu dilakukan untuk dapat menunjang proses diagnostik maupun sebagai faktor prognostik.

\section{Daftar Pustaka}

1. Kurman RJ, Carcangiu ML, Herrington $\mathrm{CS}$, Young RH. WHO Classification of Tumours of Female Reproductive Organs 4th Edition. Lyon: IARC. 2014. p 11-28.

2. Ferlay J, Soerjomataram I, Dikshit R, Eser S, Mathers C, Rebelo M, Parkin DM, Forman D, Bray F. Cancer Incidence and Mortality Worldwide: Sources, Methods and Major Patterns in GLOBOCAN 2012. International journal of cancer. 2015; 136 (5):E359-86.

3. Badan Registrasi Kanker, Perhimpunan Dokter Spesialis Patologi Indonesia. Kanker di Indonesia Tahun 2014 Data Histopatologik. Jakarta: Yayasan Kanker Indonesia. 2018.

4. Le Page C, Huntsman DG, Provencher DM, Mes-Masson AM. Predictive and Prognostic Protein Biomarkers in Epithelial Ovarian Cancer: Recommendation for Future Studies. Cancers. 2010; 2(2):91354.

5. Lowe KA, Chia VM, Taylor A, O'Malley C, Kelsh M, Mohamed M, Mowat FS, Goff B. An International Assessment of Ovarian Cancer Incidence and Mortality. Gynecologic oncology. 2013; 130(1):107-14. 
6. Vereczkey I, Serester O, Dobos J, Gallai M, Szakacs O, Szentirmay Z, et al. Molecular Characterization of 103 Ovarian Serous and Mucinous Tumors. Pathology \& Oncology Research. 2011; 17(3):551-9.

7. Rojas V, Hirshfield KM, Ganesan S, Rodriguez-Rodriguez L. Molecular Characterization of Epithelial Ovarian Cancer: Implications for Diagnosis and Treatment. International Journal of Molecular Sciences. 2016; 17 (12):2113.

8. Hauptmann S, Friedrich K, Redline R, Avril S. Ovarian Borderline Tumors in the 2014 WHO Classification: Evolving Concepts and Diagnostic Criteria. Virchows Archiv, 2017; 470(2):125-142.

9. Ushijima K, Kawano K, Tsuda N, Nishio S, Terada A, Kato H, Tasaki K, Matsukuma K. Epithelial Borderline Ovarian Tumor: Diagnosis and Treatment Strategy. Obstetrics \& gynecology science. 2015; 58(3):183-7.

10. Fischerova D, Zikan M, Dundr P, Cibula D. Diagnosis, Treatment, and Follow -up of Borderline Ovarian Tumors. The Oncologist. 2012; 17(12):1515-33.

11. Curry EW, Stronach EA, Rama NR, Wang YY, Gabra H, El-Bahrawy MA. Molecular Subtypes of Serous Borderline Ovarian Tumor Show Distinct Expression Patterns of Benign Tumor and Malignant Tumor-Associated Signatures. Modern Pathology. 2014;27 (3):433-442.

12. Morice $P$, Uzan $C$, Fauvet $R$, Gouy $S$, Duvillard P, Darai E. Borderline Ovarian Tumour: Pathological Diagnostic Dilemma and Risk Factors for Invasive or Lethal Recurrence. The Lancet Oncology. 2012;13(3):e103-15.

13. Chaudhry P, Srinivasan R, Patel FD. Differential Expression of Fas Family Members and Bcl-2 Family Members in Benign Versus Malignant Epithelial Ovarian Cancer (EOC) in North Indian Population. Molecular and Cellular Biochemistry. 2012; 368(1-2):119-126.

14. Campbell KJ, Tait SW. Targeting BCL2 Regulated Apoptosis in Cancer. Open biology. 2018; 8(5):180002.

15. Anderson NS, Turner L, Livingston $S$, Chen R, Nicosia SV, Kruk PA. Bcl-2 Expression is Altered with Ovarian Tumor progression: an Immunohistochemical Evaluation. Journal of Ovarian Research. 2009; 2(1):16.

16. Zeren $\mathrm{T}$, Inan S, Vatansever HS, Sayhan S. Significance of Apoptosis Related Proteins on Malignant Transformation of Ovarian Tumors: A Comparison between Bcl-2/Bax Ratio and p53 Immunoreactivity. Acta histochemica. 2014; 116(8):1251-8.

17. Longacre $T A$, Gilks $C B$. Surface Epithelial Stromal Tumors of the Ovary. In: Nucci MR, Olivia E. Gynecologic Pathology: A Volume in the Series: Foundations in Diagnostic Pathology. Elsevier Churcill Livingstone. 2009. p 393-426.

18. Frenzel A, Grespi F, Chmelewskij W, Villunger A. Bcl2 Family Proteins in Carcinogenesis and the Treatment of Cancer. Apoptosis. 2009; 14(4):584596.

19. Chan WY, Cheung KK, Schorge JO, Huang LW, Welch WR, Bell DA, et al. Bcl-2 and p53 Protein Expression, Apoptosis, and p53 Mutation in Human Epithelial Ovarian Cancers. The American Journal of Pathology. 2000; 156 (2):409-417.

20. Gursan N, Sipal S, Calik M, Gundogdu C. p53, Bcl-2, ki-67 li (labeling index) Status in Benign, Proliferative, and Malignant Ovarian Surface Epithelial Neoplasms. The Eurasian journal of medicine. 2009; 41(1):10. 
21. Ozer H, Yenicesu G, Arici S, Cetin M, Tuncer E, Cetin A. Immunohistochemistry with Apoptotic-Antiapoptotic Proteins (p53, p21, Bax, Bcl-2), c-kit, Telomerase, and Metallothionein as a Diagnostic Aid in Benign, Borderline, and Malignant Serous and Mucinous Ovarian Tumors. Diagnostic Pathology. 2012; 7(1):124.
22. Arik D, Kulacoglu S. p53, Bcl-2, and nm23 Expressions in Serous Ovarian Tumors: Correlation with the Clinical and Histopathological Parameters. Turk Patoloji Derg. 2011; 27(1):38-45.

23. Anderson NS, Bermudez $Y$, Badgwell $D$, Chen R, Nicosia SV, Bast Jr RC, Kruk PA. Urinary Levels of $\mathrm{Bcl}-2$ are Elevated in Ovarian Cancer Patients. Gynecologic oncology. 2009;112(1): 60-7. 